\section{Scientific breakthroughs regular events on Tokyo stock exchange}

Tokyo

What do AIDS (acquired immune deficiency syndrome) and Japan's largest fishing companies have in common? The answer is fish sperm. The link may seem obscure but when brokers on the Tokyo stock exchange recently realized that fish sperm is the raw material of AZT, a possible treatment for AIDS, shares of Nichiro Gyogyo and Nippon Suisan, giant fishing concerns, soared.

With Japan awash in paper money due to a combination of the rising yen, record low interest rates, capital inflow from overseas, and a massive trade surplus, it is boom time on the Tokyo exchange, and the past four months have seen a series of mad upswings in the market riding on the wings of science and technology. First came the AIDS rush in late January after the announcement of the first death of a Japanese woman from the disease (Nature 325, 382; 1987). Shares related to AIDS prevention, treatment or testing soared: stocks of Fuji Rebio, a company that has developed the gelatin particle aggulination method for screening blood (Nature 323, 384; 1986) doubled in value, and shares of Okamoto, a company reputed to make the world's best condoms, the "skinless skin" made of rubber a mere 100 micrometres thick, quadrupled.

In other cases, the relationship to AIDS was more tenuous. Ueno Seiyaku, a drug maker, announced a new compound that halted AIDS virus proliferation in vitro. To the dismay of share dealers, the company was not listed on the stock exchange. But, undeterred, the money-makers latched on to Kyowa Hakko, the world's

largest amino-acid producer, driving up its share price on the basis of a rumour that it would make a licensing agreement with Ueno Seiyaku. In fact, their only relation was that Kyowa Hakko had sold some drugs for the other company.

Now the market has discovered hightemperature superconductivity. First to be singled out were companies listed on a research committee set up by the Science and Technology Agency in February, after Che et al.'s announcement of superconductivity in barium-yttrium-copper oxide at $93 \mathrm{~K}$. Prominent among them was Fujikura Densen, an electric cable manufacturer whose shares rocketed from Y465 in early February to Y884 on 5 May. As company after company announced "breakthroughs", the market responded - on 2 April, Toshiba's shares jumped Y40 when the company announced development of wire made from the new ceramics (Nature 326, 533; 1987). That the current-carrying capacity of the wire was a mere $6 \mathrm{~A} \mathrm{~cm}^{-2}$, five or six orders of magnitude below that for practical applications, did not deter investors.

Such fluctuations are not new to the Tokyo exchange. In early 1985 , shares of Asahi Chemical Industry Co. Ltd soared when the company announced the cloning and expression of human tumour necrosis factor (TNF) (Nature 313, 803; 1985) but they soon fell back when it became clear that TNF is not a miracle cure for cancer. At the same time, shares of Yamanouchi Pharmaceutical Co. rose on a rumour of a more effective anticancer agent, 'KBS'. To this day nobody knows what KBS was.

David Swinbanks

\title{
Star Wars proponents question physicists' beam weapon report
}

\section{Washington}

SuPPORTERS of the Strategic Defense Initiative (SDI) have fired the first round in what may turn into a sniping war over the technical merits of the American Physical Society (APS) report on directed energy weapons (Nature 326, 815; 1987). The Science and Engineering Committee for a Secure World, a mostly academic organization devoted to the SDI cause, is publicizing charges made by Gregory Canavan, of Los Alamos National Laboratory, and Lowell Wood, of Lawrence Livermore. They say that the APS study was seriously flawed, containing an accumulation of errors that all make space defence look harder than it really is.

Wood and Canavan's chief point, that the report underestimated the power achieved by chemical lasers, illustrates the nature of the dispute. The APS panel takes the state of the art to be a laser of 200 $\mathrm{kW}$ with adequate beam quality, and says that an increase of power by a factor of one hundred is needed; Wood and Canavan counter that powers of more than a million watts have been achieved but, as they admit, with poorer beam quality. Exactly how much improvement of what is needed for a working weapon?

Arguments such as these show how difficult it is to arrive at definitive answers to ill-defined questions. Because the APS report sets out numerous unsolved technical difficulties but rarely goes so far as to say the problems are insoluble, it leaves room for SDI proponents to call for more research.

\section{Hungary on the ball}

\section{London}

THE Hungarian Ministry of Industry has established a special research group to investigate possible practical applications of the new superconducting ceramics. The group, headed by Deputy Minister of Industry Arpad Vörös, was set up after a research team at Budapest's Eötvös Lorand University announced the production of a superconducting yttriumbarium-copper oxide ceramic. Last month, the Eötvös Lorand team announced that superconductivity was achieved at $105 \mathrm{~K}$. The initial drop in resistivity was observed at $173 \mathrm{~K}$. The room temperature resistivity of the specimen was very high, at $0.4 \mathrm{ohm} \mathrm{cm}$.

The team, under Dr Jozsef Bankuti, is now investigating the structure of the ceramic using scanning electron microscopy, X-ray diffraction and chemical and microprobe methods. No observations, have so far been made on the Josephson effect, but a Meissner effect of about 21 per cent was observed at $77 \mathrm{~K}$.

V.R.

\section{UK superconductivity}

\section{London}

Moves to organize a coordinated strategy between Britain's industry and universities for research into high-temperature superconductors have been initiated by the government's chief scientific adviser, $\mathrm{Mr}$ John Fairclough. Representatives of the Cabinet office, the Department of Trade and Industry (DTI) and the Science and Engineering Research Council (SERC) met on 12 May and were due to meet again last week. DTI is expected to meet industrial research directors soon.

Professor Laurie Challis, chairman of the SERC physics committee, says "This is a very hopeful sign which implies that the government is recognizing that this is a special area needing special financial treatment."

S.L.H.

\section{Centred on technology}

\section{London}

BULGARIA is to establish a network of technological centres to undertake the "technological re-equipping" of the Bulgarian economy. According to Lyubomir Dachev, the deputy chairman of the State Committee for Research and Technology, the centres will concentrate on the many branches of the economy. They will design new equipment, work out plans for the updating of existing capabilities, train specialists and build small high-technology enterprises. Some 25 such centres are planned, in fields including electronics, automation and laser equipment. They will be run by governing councils, Dachev said, and will be entitled to conclude contracts with economic enterprises and to participate in the drawing up of the state economic plan. 